\title{
SIXTH ANNUAL LIST OF PAPERS
}

\section{READ BEFORE THE AMERICAN MATHEMATICAL SOCIETY AND} SUBSEQUENTLY PUBLISHED, INCLUDING REFERENCES

TO THE PLACES OF THEIR PUBLICATION.

BôcHer, M. On Certain Methods of Sturm and their Application to the Roots of Bessel's Functions. Read Feb. 27, 1897. Bulletin of the American Mathematical Society, vol. 3, No. 6, pp. 205-213 ; March, 1897.

Brown, E. W. The Theoretical Values of the Mean Motions of the Lunar Perigee and Node. Read Dec. 30, 1896. Monthly Notices of the Royal Astronomical Society, vol. 57, No. 5, pp. 332-349; March, 1897.

Davis, E. W. On the Continuity of Chance. Read Sept. 1, 1896. Nebraska University Studies, vol. 2, No. 2, pp. 131-146 ; Jan., 1897.

- A Geometrical Picture of the Fifteen School Girl Problem. Read (Chicago) Jan. 1, 1897. Annals of Mathematics, vol. 11, No. 5, pp. 156-157; June, 1897.

- A Note on the Invariance of the Factors of Composition of a Group. Read (Chicago) Dec. 31, 1896. American Journal of Mathematics, vol. 19, No. 2, p. 191 ; April, 1897.

Dickson, L. E. The Analytic Representation of Substitutions on a Power of a Prime Number of Letters, with a Discussion of the Linear Group. Read Aug. 31, 1896. Annals of Mathematics, vol. 11, Nos. 3 and 4, pp. 65-120, Feb.-Apr., 1897.

- A Triply-Infinite System of Simple Groups. Read Aug. 31, 1896. Quarterly Journal of Mathematics. vol. 29, No. 114, pp. 167-178; July, 1897.

- Systems of Continuous and Discontinuous Simple Groups. Read April 24, 1897. Bulletin of the American Mathematical Society, vol. 3, No. 8, pp. 265-273 ; May, 1897.

Fiske, T. S. Note on the Integration of a Uniformly Convergent Series Through an Infinite Interval. Read Jan. 30, 1897. Bulletin of the American Mathematical Society, vol. 3, No. 6, pp. 223-224; March, 1897.

HILL, J. E. Bibliography of Surfaces and Twisted Curves. Read May 23, 1896. Bulletin of the American Mathematical Society, vol. 3, No. 4, pp. 133-146 ; Jan. 1897.

Hutchinson, J. I. A Special Form of Quartic Surface. Read Aug. 31. 1897. Annals of Mathematics, vol. 2, No. 5, pp. 158-160 ; June, 1897,

Hyde, E. W. Loci of the Equations $p=\phi^{u} e$ and $p=\phi^{u} \psi^{v} e$. Read Aug. 31, 1896. Zeitschrift für Mathematik und Physik, vol. 42, No. 3, pp. 122-132; July, 1897.

KLEIN, F. On the Stability of a Sleeping Top. Read (Princeton Meeting) Oct. 17, 1896. Abstract in Bulletin of the American Mathematical Society, vol. 3, No. 4, pp. 129-132; Jan. 1897. [Errata noted in vol. 3, No. 8, p. 292.] 
McClintock, E. On the Most Perfect Forms of Magic Squares, with Methods for their Production. Read April 25, 1896. American Journal of Mathematics, vol. 19, No. 2, pp. 99-120 ; April, 1897.

- On a Solution of the Biquadratic which Combines the Method of Descartes and Euler. Read May 29, 1897. Bulletin of the American Mathematical Society, vol. 3, No. 10, pp. 389-390 ; July, 1897.

Martin, A. Formulas for the sides of Rational Plane Triangles. Read Aug. 27, 1895. Mathematical Magazine, vol. 2, No. 11, pp. 221-236; [No. incomplete, undated.]

- A Method of Finding, Without Tables, the Number Corresponding to a Given Logarithm. Read Sept. 1, 1896. Mathematical Magazine, vol. 2, No. 11, pp. 237-240; [No. incomplete, undated.]

MILler, G. A. On the Transitive Substitution Groups whose Orders are the Products of Three Prime Numbers. Read Jan. 30, 1897. Bulletin of the American Mathematical Society, vol. 3, No. 6, pp. 21322:; March, 1897.

Moore, E. H. The Decomposition of Modular Systems of Rank $n$ in $n$ Variables. Read (Chicago) April 24, 1897. Bulletin of the American Mathematical Society, vol. 3, No. 10, pp. 372-380; July, 1897.

OsGood, W. F. A Geometrical Method for the Treatment of Uniform Convergence and Certain Double Limits. Read Aug. 31, 1896. Bulletin of the American Mathematical Society, vol. 3, No. 2, pp. 59-86; Nov., 1896.

- Non-Uniform Convergence and the Integration of Series Term by Term. Read Aug. 31, 1896. American Journal of Mathematics, vol. 19, No. 2, pp. 155-190; April, 1897.

Perrae, B. O. and Wrllson, R. W. Table of the First Forty Roots of the Bessel Equation $J_{0}(x)=0$ with the Corresponding Values of $J_{1}(x)$. Read Sept. 1, 1896. Bulletin of the American Mathematical Society, vol. 3, No. 4, ṕ. 153-155 ; Jan., 1897.

Pierpont, J. P. On Modular Equations. Read March 27, 1897. Bulletin of the American Mathematical Society, vol. 3, No. 8, pp. 279-292 ; May, 1897.

Porter, M. B. On the Number of Roots of the Hypergeometric Senir Between Ten and One. Read March 27, 1897. Bulletin of the American Mathematical Society, vol. 3, No. 8, pp. 274-278; May, 1897.

Row, E. D. Two Developments. Read Jan. 30, 1897. American Mathematical Monthly, vol. 4, No. 3, pp. 82-86; March, 1897.

Scotr, C. A. On Cayley's Theory of the Absolute. Read Jan. 30, 1897, Bulletin of the American Mathematical Society, vol. 3, No. 7, pp. 235246 ; April, 1897.

SHAw, J. B. The Linear Vector Operator of Quaternions. Read Aug. 27, 1895. American Journal of Mathematics, vol. 19, No. 3, pp. 267282 ; July, 1897.

SNYDER, V. Criteria for the Reality of Nodes in Dupin's Cyclides, with a Corresponding Classification. Read Sept. 1, 1896. Annals of Mathematics, vol. 11, No. 5, pp. 137-147 ; June, 1897.

- Lines Common to Four Linear Complexes. Read Feb. 27, 1897. Bulletin of the American Mathematical Society, vol. 3, No. 7, pp. 247250 ; April, 1897. 
TABER, H. Notes on the Theory of Bilinear Forms. Read Nov. 28, 1896. Bulletin of the American Mathematical Society, vol. 3, No. 4, pp. 156-164 ; Jan., 1897.

WHITE, H. S. Numerically Regular Reticulations Upon Surfaces of Deficiency Higher than 1. Read Sept. 1, 1896. Bulletin of the American Mathematical Society, vol. 3, No. 3, pp. 116-121; Dec. 1896.

- The Cubic Resolvent of a Binary Quartic Derived by Invariant Definition and Process. Read (Chicago) Jan. 1, 1897. Bulletin of the American Mathematical Society, vol. 3, No. 7, pp. 250-253; April, 1897.

Willson, R. W. and Peirce, B. O. Table of the First Forty Roots of the Bessel Equation $J_{0}(x)=0$, with the Corresponding Values of $J_{1}(x)$. Read Sept. 1, 1896. Bulletin of the American Mathematical Society, vol. 3, No. 4, pp. 153-155 ; Jan., 1897. 